\title{
Haloanaerobium salsugo sp. nov., a Moderately Halophilic, Anaerobic Bacterium from a Subterranean Brine
}

\author{
V. K. BHUPATHIRAJU, ${ }^{1}$ A. OREN,${ }^{2}$ P. K. SHARMA, ${ }^{1}$ R. S. TANNER, ${ }^{1}$ C. R. WOESE, ${ }^{3}$ \\ AND M. J. MCINERNEY ${ }^{1 *}$ \\ Department of Botany and Microbiology, University of Oklahoma, Norman, Oklahoma 73019 $;$ The Moshe Shilo \\ Center for Marine Biogeochemistry and the Institute of Life Sciences, The Hebrew University of Jerusalem, Jerusalem \\ 91904, Israel' ; and the Department of Microbiology, University of Illinois, Urbana, Illinois $61801^{3}$
}

\begin{abstract}
A strictly anaerobic, moderately halophilic, gram-negative bacterium was isolated from a highly saline oil field brine. The bacterium was a non-spore-forming, nonmotile rod, appearing singly, in pairs, or occasionally as long chains, and measured 0.3 to 0.4 by 2.6 to $4 \mu \mathrm{m}$. The bacterium had a specific requirement for $\mathrm{NaCl}$ and grew at $\mathrm{NaCl}$ concentrations of between 6 and $24 \%$, with optimal growth at $9 \% \mathrm{NaCl}$. The isolate grew at temperatures of between 22 and $51^{\circ} \mathrm{C}$ and $\mathrm{pH}$ values of between 5.6 and 8.0. The doubling time in a complex medium containing $10 \% \mathrm{NaCl}$ was $9 \mathrm{~h}$. Growth was inhibited by chloramphenicol, tetracycline, and penicillin but not by cycloheximide or azide. Fermentable substrates were predominantly carbohydrates. The end products of glucose fermentation were acetate, ethanol, $\mathrm{CO}_{2}$, and $\mathrm{H}_{2}$. The major components of the cellular fatty acids were $C_{14: 0}, C_{16: 0}, C_{16: 1}$, and $C_{17: 0 \text { cyc }}$ acids. The DNA base composition of the isolate was 34 mol\% $\mathrm{G}+\mathrm{C}$. Oligonucleotide catalog and sequence analyses of the 16S rRNA showed that strain VS-752 ${ }^{\mathrm{T}}$ was most closely related to Haloanaerobium praevalens GSL $^{T}$ (ATCC 33744), the sole member of the genus Haloanaerobium. We propose that strain VS-752 (ATCC 51327) be established as the type strain of a new species, Haloanaerobium salsugo, in the genus Haloanaerobium.
\end{abstract}

Hypersaline environments are inhabited by diverse groups of bacteria. Most studies of bacteria from these environments have focused on aerobes $(34,35)$. Our understanding of fermentative halophilic anaerobic bacteria has increased over the last decade. Five genera have been described to date: Halobacteroides, which includes Halobacteroides halobius (24, 38), Halobacteroides acetoethylicus (27), and Halobacteroides lacunaris (39); Haloanaerobium, which includes Haloanaerobium praevalens (36); Sporohalobacter, which includes Sporohalobacter lortettii (23) and Sporohalobacter marismortui (23); Haloanaerobacter, which includes Haloanaerobacter chitinovorans (14); and Haloincola, which includes Haloincola saccharolytica (40). With the exception of $H$. acetoethylicus and $H$. chitinovorans, $16 \mathrm{~S}$ or $5 \mathrm{~S}$ rRNA sequences have been determined for these halophiles. These bacteria were placed in the family Haloanaerobiaceae on the basis of analysis of the sequences $(22-24,40)$.

Most of the fermentative halophilic anaerobes described to date were isolated from the Dead Sea, cyanobacterial mat lagoons, solar salterns, or hypersaline salt lakes. There has been only one report of the isolation of a fermentative halophilic anaerobe from oil field brines (9), although a halophilic anaerobe has been isolated from oil-water injection filters (27). Methanogenic $(2,9,20)$ and sulfate-reducing $(3,4)$ bacteria have been isolated from oil field brines. The fermentative organism described by Gervertz et al. (9) was an obligate anaerobe with an optimal salt requirement of $2.5 \% \mathrm{NaCl}$ and a low salt tolerance range $(2.5$ to $10 \% \mathrm{NaCl})$. There is no information regarding the occurrence of fermentative haloanaerobes in oil brines with $\mathrm{NaCl}$ concentrations above $10 \%$.

A variety of halophilic, fermentative, sulfate-reducing, and methanogenic bacteria were isolated from highly saline oil field brines during a microbially enhanced oil recovery field pilot

\footnotetext{
* Corresponding author. Mailing address: Department of Botany and Microbiology, 770 Van Vleet Oval, University of Oklahoma, Norman, OK 73019-0245. Phone: (405) 325-6050. Fax: (405) 325-7619.
}

study (3). In the present study, the characterization of a strictly anaerobic, moderately halophilic, fermentative bacterium from this oil field is described. The phenotypic and phylogenetic characteristics of this organism were significantly different from the characteristics of all previously described halophilic fermentative anaerobes and justify its designation as a new species, Haloanaerobium salsugo, in the genus Haloanaerobium. The type strain is VS-752.

\section{MATERIALS AND METHODS}

Strains. $H$. acetoethylicus ATCC $43120^{\mathrm{T}}, H$. praevalens ATCC $33744^{\mathrm{T}}$, and $S$. lortetii ATCC $35059^{\mathrm{T}}$ were obtained from American Type Culture Collection, Rockville, Md. Strain VS-752 ${ }^{\mathrm{T}}$ was isolated from a hypersaline oil brine (3) and deposited in the American Type Culture Collection as ATCC 51327.

Bacterial isolation. Anaerobic heterotrophic halophilic bacteria were isolated from petroleum reservoir production fluids from wells 5-1, 7-3, and 7-5 of the Southeast Vassar Vertz Sand Unit, Payne County, Okla., using plate count agar (Difco Laboratories, Detroit, Mich.) with $15 \% \mathrm{NaCl}$ (3). Colonies were picked and restreaked several times to obtain pure cultures. A total of 36 anaerobic fermentative halophilic strains were isolated. The morphology, the products produced from glucose, the sugars used to support growth, and the $\mathrm{G}+\mathrm{C}$ content (moles percent) of two of these strains were similar to those of strain VS-752 ${ }^{\mathrm{T}}$. Strain VS-752 ${ }^{\mathrm{T}}$ was chosen for further characterization.

Media and culture methods. The mineral medium contained the following components (grams per liter): $\mathrm{NaCl}, 120 ; \mathrm{NH}_{4} \mathrm{Cl}$, $1.0 ; \mathrm{KCl}, 0.1 ; \mathrm{KH}_{2} \mathrm{PO}_{4}, 0.1 ; \mathrm{MgSO}_{4} \cdot 7 \mathrm{H}_{2} \mathrm{O}, 0.2 ; \mathrm{CaCl}_{2} \cdot 2 \mathrm{H}_{2} \mathrm{O}$, 0.04 ; PIPES (piperazine- $N, N^{\prime}$-bis[2-ethanesulfonic acid]) dipotassium salt, 1.5; yeast extract, 0.25 ; resazurin, 0.0005 ; cysteine hydrochloride, 0.5 ; and $\mathrm{Na}_{2} \mathrm{~S} \cdot 9 \mathrm{H}_{2} \mathrm{O}, 0.5$, as well as $5 \mathrm{ml}$ of trace metal solution (32), $10 \mathrm{ml}$ of vitamin solution (1), and a $\mathrm{N}_{2}$ gas phase. The $\mathrm{pH}$ was 7.1 to 7.3 . A complex medium contained the mineral medium described above supplemented 


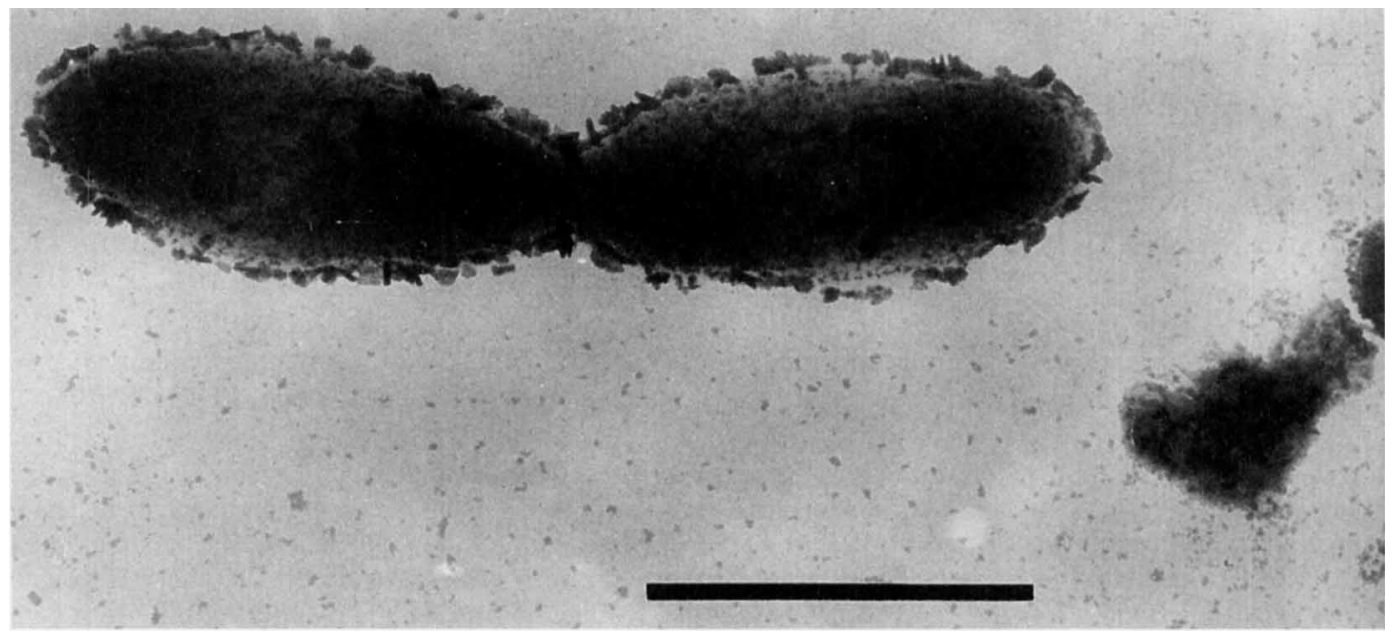

FIG. 1. Transmission electron micrograph of a negatively stained whole cell of $H$. salsugo VS-752T. Bar, $1 \mu \mathrm{m}$.

with the following components (grams per liter): Casamino Acids, 1.0; yeast extract, 1.0; and glucose, 5.0. Solid media were prepared by the addition of $20 \mathrm{~g}$ of purified agar per liter (BBL Microbiology Systems, Cockeysville, Md.). The methods for the preparation and use of anaerobic media were those of Balch and Wolfe (1). Cultures were routinely maintained in a complex medium by transfer once every week.

Metabolic and growth characteristics. The $\mathrm{NaCl}$ range for growth was determined with complex medium containing 0 to $30 \% \mathrm{NaCl}$. The specific requirement for $\mathrm{NaCl}$ was examined with basal medium containing $8 \mathrm{~g}$ of glucose per liter by substituting other salts at concentrations of $0.5,1.0,1.5,2.0$, and $2.5 \mathrm{M}$. $\mathrm{KCl}, \mathrm{LiCl}, \mathrm{MgCl}_{2} \cdot 6 \mathrm{H}_{2} \mathrm{O}$, and $\mathrm{NH}_{4} \mathrm{Cl}$ were used to test for a specific $\mathrm{Na}^{+}$requirement. The $\mathrm{Cl}^{-}$requirement was examined with $\mathrm{NaBr}, \mathrm{NaNO}_{3}, \mathrm{NaSO}_{4}$, and $\mathrm{Na}_{2} \mathrm{~S}_{2} \mathrm{O}_{3}$. Results were compared with those from positive control tubes containing $\mathrm{NaCl}$. The temperature range for growth was determined with complex medium incubated at 5 to $65^{\circ} \mathrm{C}$. The $\mathrm{pH}$ dependence of growth was tested in complex medium with $100 \mathrm{mM}$ 3-( $N$-morpholino)-propanesulfonic acid (MOPS) buffer and a $\mathrm{N}_{2}$ gas phase. The effect of external electron acceptors on growth was tested with mineral medium with glucose $(10 \mathrm{mM})$ as an electron donor. Compounds tested as electron acceptors included elemental sulfur, sodium sulfate, sodium thiosulfate, sodium sulfite, sodium nitrate, and sodium nitrite at a concentration of $3 \mathrm{~g} /$ liter.

The ability of $H$. salsugo VS-752 ${ }^{\mathrm{T}}, H$. praevalens $\mathrm{GSL}^{\mathrm{T}}$, and $H$. acetoethylicus $\mathrm{EIGI}^{\mathrm{T}}$ to utilize different substrates was tested in mineral medium with the test compound at $10 \mathrm{mM}$. Complex substrates were added at a concentration of $5 \mathrm{~g} /$ liter. The use of a compound or combination of compounds was scored positive after growth occurred in at least three serial transfers. The ability to utilize amino acid mixtures was also tested. The amino acid combinations tested included alanineglycine, leucine-proline, isoleucine-tryptophan, valine-ornithine, phenylalanine-leucine, and histidine-sarcosine.

Glucose fermentation products were determined with mineral medium containing $10 \mathrm{~g}$ of glucose per liter and a $\mathrm{N}_{2}$ gas phase. Volatile fatty acids and alcohols in the liquid phase and $\mathrm{CO}_{2}$ and $\mathrm{H}_{2}$ in the gas phase were analyzed at the beginning of the experiment and after 4 days of incubation. A molar growth yield was determined for a $50-\mathrm{ml}$ batch culture containing mineral medium supplemented with $4 \mathrm{~g}$ of glucose per liter.
Unless otherwise mentioned, all experiments were performed in duplicate or triplicate at $37^{\circ} \mathrm{C}$.

Gram staining was performed with both heat-fixed smears and smears fixed with acetic acid as described previously (8). Antibiotic susceptibility tests were performed by adding various filter-sterilized antibiotics to the growth medium. Antibiotics tested included chloramphenicol, tetracycline, penicillin, and cycloheximide, each at $10 \mu \mathrm{g} / \mathrm{ml}$. Sodium azide was tested at $50 \mu \mathrm{g} / \mathrm{ml}$. Susceptibility to the inhibitors described above was determined by comparing growth in medium containing the inhibitor to growth in controls that lacked the inhibitor. Catalase and oxidase tests were also performed (31).

Analytical techniques. Growth was monitored by measuring the increase in $A_{660}(1)$. Measurement of $\mathrm{pH}$ was done with a $\mathrm{pH}$ meter equipped with a triode $\mathrm{pH}$ electrode with a $\mathrm{Ag}-\mathrm{AgCl}$ internal reference system. Glucose was measured by the glucose oxidase method (Sigma Chemical Co., St. Louis, Mo.). Volatile fatty acids and alcohols were analyzed by gas chromatography (4). Fatty acid analyses were also performed with a high-performance liquid chromatograph (HPLC) equipped with a Bio-Rad Aminex HPX-87H column ( 300 by $7.8 \mathrm{~mm}$ ) and an isocratic mobile phase of $0.016 \mathrm{~N} \mathrm{H}_{2} \mathrm{SO}_{4}$ at a flow rate of $0.9 \mathrm{ml} / \mathrm{min}$. Hydrogen was analyzed with an RGA 3 reduction gas analyzer source fitted with a 3 - $\mathrm{ft}$ by $1 / 8$-in. (91.44- by $0.32-\mathrm{cm}$ ) column packed with $60 / 80$ mesh Spherocarb operated at a temperature of $90^{\circ} \mathrm{C}$. Nitrogen was the carrier gas at 20 $\mathrm{ml} / \mathrm{min}$. Carbon dioxide was measured with a gas chromatograph equipped with a thermal conductivity detector and a Porapack Q column (Supleco, Inc., Bellefonte, Pa.) (10). All gas analyses were performed with gas-tight syringes.

Microscopy. Cellular morphology was determined by phasecontrast microscopy. Transmission electron microscopy was performed with a JEOL JEM $2000 \mathrm{FX}$ transmission electron microscope. Micrographs were prepared from log-phase cells grown on a complex medium. The cells were spread onto carbon-coated Formvar grids, fixed with $1 \%$ glutaraldehyde in $9 \% \mathrm{NaCl}$, and stained with $1 \%$ phosphotungstic acid ( $\mathrm{pH} 7.0$ ).

Cellular fatty acid analysis. The cellular fatty acid composition of $H$. salsugo VS-752 $2^{\mathrm{T}} H$. praevalens $\mathrm{GSL}^{\mathrm{T}}$, and $H$. acetoethylicus $\mathrm{EIGI}^{\mathrm{T}}$ was determined with cells grown in the complex medium containing $10 \% \mathrm{NaCl}$. Cellular fatty acid analysis was performed by Microcheck, Inc., Northfield, Vt. Whole-cell fatty acids were analyzed as fatty acid methyl esters 
with a MIDI microbial identification system (MIDI, Inc., Newark, Del.). Fatty acid methyl esters were synthesized and analyzed as described previously $(18,19,28)$.

Determination of DNA base composition. DNA was isolated and purified as described previously (16). The $\mathrm{G}+\mathrm{C}$ content was determined by the HPLC method of Mesbah et al. (17). Nonmethylated lambda virus DNA (BioLabs, lot 33) was used for calibration.

16S rRNA sequence analysis. $H$. salsugo VS-752 ${ }^{\mathrm{T}}$ (ATCC 51327 ) was grown on complex medium containing $10 \% \mathrm{NaCl}$. The 16S rRNAs from $H$. salsugo VS-752 ${ }^{\mathrm{T}}, H$. praevalens $\mathrm{GSL}^{\mathrm{T}}$ (DSM 2228 [ATCC 33744]), and S. lortetii MD-2 ${ }^{\mathrm{T}}$ (DSM 3070 [ATCC 35059]) were sequenced by methods described previously $(13,25)$. Strain and $16 \mathrm{~S}$ rRNA sequence information for Chromatium vinosum, Clostridium aminovalericum, Clostridium barkeri, Clostridium butyricum, Clostridium lituseburense, Clostridium pasteurianum, Clostridium quercicolum, Clostridium thermoaceticum, Clostridium thermosaccharolyticum, Desulfovibrio desulfuricans, Heliobacterium chlorum, and Syntrophomonas wolfei have been published previously $(7,26,33,37)$. Sequences were analyzed by distance matrix analysis with a program for fitting trees to distance data $(6,12,25)$.

Nucleotide sequence accession number. The $16 \mathrm{~S}$ rRNAs of $H$. salsugo VS-752 ${ }^{\mathrm{T}}, H$. praevalens $\mathrm{GSL}^{\mathrm{T}}$, and $S$. lortetii $\mathrm{MD}-2^{\mathrm{T}}$ determined in this study were deposited in GenBank under the accession numbers L22890, M59123, and M59122, respectively.

\section{RESULTS AND DISCUSSION}

Cellular and colonial morphology. Strain VS- $752^{\mathrm{T}}$ was a gram-negative, non-spore-forming, rod-shaped bacterium (Fig. 1). The cells were nonmotile, characteristically appearing singly, in pairs, or occasionally as long chains, and measured 0.3 to 0.4 by 2.6 to $4 \mu \mathrm{m}$. Colonies on complex medium were circular, entire, opaque, white, and 1 to $2 \mathrm{~mm}$ in diameter.

Metabolic and growth characteristics. Strain VS- $752^{\mathrm{T}}$ required anaerobic conditions for growth. The organism was an obligate halophile that grew in medium containing 6 to $24 \%$ $\mathrm{NaCl}$ (Fig. 2A). At $\mathrm{NaCl}$ concentrations below $6 \%$, the cells lysed. Optimum growth occurred in medium containing $9 \%$ $\mathrm{NaCl}$. Strain VS-752 ${ }^{\mathrm{T}}$ had a specific requirement for $\mathrm{NaCl} . \mathrm{K}^{+}$, $\mathrm{Mg}^{2+}, \mathrm{Li}^{+}$, and $\mathrm{NH}_{4}{ }^{+}$salts did not support growth. The chloride ion could not be replaced by $\mathrm{Br}^{-}, \mathrm{NO}_{3}{ }^{-}, \mathrm{SO}_{4}{ }^{2-}$, or $\mathrm{S}_{2} \mathrm{O}_{3}{ }^{2-}$. The temperature range for growth was 22 to $51^{\circ} \mathrm{C}$ (Fig. 2B). The optimum growth temperature was $40^{\circ} \mathrm{C}$. The $\mathrm{pH}$ range was 5.6 to 8.0 (Fig. 2C). The $\mathrm{pH}$ optimum was 6.1 to 6.5 . The doubling time in complex medium $(10 \% \mathrm{NaCl}, \mathrm{pH} 7.0$, $37^{\circ} \mathrm{C}$ ) was $9 \mathrm{~h}$.

None of the electron acceptors tested stimulated the growth of strain VS-752 $2^{\mathrm{T}}$ in glucose mineral medium. Elemental sulfur, sulfate, thiosulfate, sulfite, and nitrite inhibited the growth of the organism. Nitrate did not affect the growth of the organism. The change of the gas phase composition from $\mathrm{N}_{2} / \mathrm{CO}_{2}(80: 20)$ to $\mathrm{H}_{2} / \mathrm{CO}_{2}(80: 20)$ did not affect growth. The presence of $\geq 25 \%$ carbon monoxide in the gas phase inhibited growth in the mineral medium with or without glucose.

Substrates supporting growth of strain VS-752 $2^{\mathrm{T}}$ are listed in Table 1 . The substrates used by strain VS- $752^{\mathrm{T}}$ were predominantly carbohydrates. Those that gave the best growth $\left(\Delta A_{660}\right.$, $>0.4$ ) were maltotriose, D-mannose, fructose, maltose, raffinose, sucrose, galactose, glucose, and lactose. Good growth $\left(\Delta A_{660}, 0.15\right.$ to 0.4$)$ was observed with L-arabinose, $N$-acetylglucosamine, glucosamine, melibiose, D-ribose, L-sorbose, trehalose, D-xylose, and yeast extract. Poor growth $\left(\Delta A_{660}, 0.05\right.$ to 0.15 ) was observed with rhamnose, pyruvate, and melizitose. Substrates that did not support growth included L-alanine,
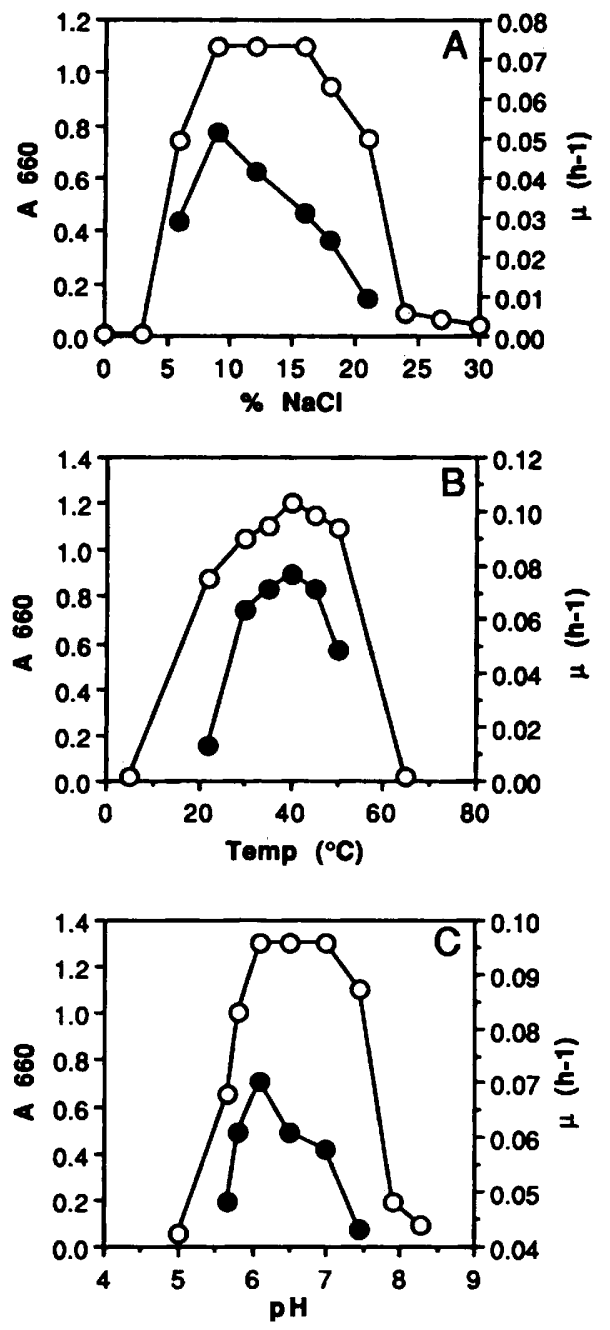

FIG. 2. Effect of $\mathrm{NaCl}$ concentration (A), temperature (B), and $\mathrm{pH}$ (C) on growth $(\mathrm{O})$ and growth rate $(\mathrm{O})$ of $H$, salsugo $\mathrm{VS}-752^{\mathrm{T}}$ in complex medium. $\mu$ (h-1), growth rate per hour.

L-ascorbate, adonitol, betaine, butyrate, chitin, crotonate, Casamino Acids, dextran, dextrin, dulcitol, ethylene glycol, formate, fucose, fumarate, glycerol, glutamate, glycine, glycogen, D-gluconate, inositol, inulin, L-lysine, lactate, malate, methanol, mannitol, methionine, pectin, proline, propionate, peptone, starch, succinate, sarcosine, sorbitol, salicin, trypticase, whey, and xylan. Amino acid mixtures such as alanineglycine, leucine-proline, isoleucine-tryptophan, valine-ornithine, phenylalanine-leucine, and histidine-sarcosine did not support growth.

Strain VS $-752^{\mathrm{T}}$ fermented glucose, with the production of acetate, ethanol, $\mathrm{CO}_{2}$, and $\mathrm{H}_{2}$ (Table 2). Lactate, malate, succinate, butyrate, propionate, valerate, isovalerate, and caproate were not detected in the culture fluids. The molar growth yield was $24.5 \pm 0.3 \mathrm{~g}$ (dry weight) $/ \mathrm{mol}$ of glucose.

The growth of strain VS- $752^{\mathrm{T}}$ was inhibited by chloramphenicol, tetracycline, and penicillin. Cycloheximide and azide did not inhibit growth. The cells were catalase and oxidase negative.

Cellular fatty acid composition. The cell membrane fatty acid composition of strain VS-752 ${ }^{\mathrm{T}}$ is shown in Table 3 . Cellular fatty acids of $H$. acetoethylicus $\mathrm{EIGI}^{\mathrm{T}}$ and $H$. praeva- 
TABLE 1. Substrate utilization by $H$. salsugo VS-752 ${ }^{\mathrm{T}}, H$. praevalens $\mathrm{GSL}^{\mathrm{T}}$, and $H$. acetoethylicus $\mathrm{EIGI}^{\mathrm{T}}$

\begin{tabular}{lccc}
\hline \multirow{2}{*}{ Substrate } & \multicolumn{3}{c}{ Utilization by $^{a}$ : } \\
\cline { 2 - 4 } & $\begin{array}{c}\text { H. salsugo } \\
\text { VS-752 }\end{array}$ & $\begin{array}{c}\text { H. praevalens } \\
\text { GSL }^{\mathrm{T}}\end{array}$ & $\begin{array}{c}\text { H. acetoethylicus } \\
\text { EIGI }^{\mathrm{T}}\end{array}$ \\
\hline L-Arabinose & + & - & + \\
N-Acetylglucosamine & + & + & + \\
Cellobiose & - & - & + \\
Fructose & + & + & + \\
Galactose & + & - & - \\
Glucosamine & + & + & + \\
D-Glucose & + & + & + \\
Lactose & + & - & + \\
Maltotriose & + & + & + \\
Melizitose & + & - & + \\
D-Mannose & + & + & + \\
Maltose & + & + & - \\
Melibiose & + & - & - \\
Pectin & - & + & + \\
Pyruvate & + & - & + \\
D-Ribose & + & ND & + \\
Rhamnose & + & - & + \\
Raffinose & + & - & + \\
Sucrose & + & - & - \\
L-Sorbose & + & - & + \\
Trehalose & + & - & + \\
Whey & - & ND & + \\
D-Xylose & + & - & + \\
\hline
\end{tabular}

${ }^{a}$ Cultures were grown as described in the text. + , supported growth; - , did not support growth; ND, not determined.

lens $\mathrm{GSL}^{\mathrm{T}}$ were also determined for comparison. All cultures were grown under similar conditions. The major $(>7 \%)$ membrane fatty acids present in strain VS-752 ${ }^{\mathrm{T}}$ were $\mathrm{C}_{14: 0}, \mathrm{C}_{16: 0}$, $\mathrm{C}_{16: 1}$, and $\mathrm{C}_{17: 0 \text { cyc }}$ acids. The minor $(0.5$ to $7 \%)$ fatty acids included $\mathrm{C}_{10: 0}, \mathrm{C}_{12: 0}$, and $\mathrm{C}_{15: 0}$ acids. The fatty acid profiles of $H$. acetoethylicus $\mathrm{EIGI}^{\mathrm{T}}$ and $H$. praevalens $\mathrm{GSL}^{\mathrm{T}}$ were similar to each other. The major fatty acids in both organisms were $\mathrm{C}_{14: 0}, \mathrm{C}_{16: 0}$, and $\mathrm{C}_{16: 1}$ acids, with $\mathrm{C}_{16: 1}$ cis-9 acid being the predominant component (ca. 34\%). The minor fatty acids found in both $H$. acetoethylicus $\mathrm{EIGI}^{\mathrm{T}}$ and $H$. praevalens $\mathrm{GSL}^{\mathrm{T}}$ were $\mathrm{C}_{10: 0}, \mathrm{C}_{12: 0}, \mathrm{C}_{14: 1}, \mathrm{C}_{15: 0}, \mathrm{C}_{18: 0}$, and $\mathrm{C}_{18: 1}$ acids, and, in addition to these acids, $H$. acetoethylicus $\mathrm{EIGI}^{\mathrm{T}}$ and $H$. praevalens $\mathrm{GSL}^{\mathrm{T}}$ contained $\mathrm{C}_{17: 0 \text { cyc }}$ acid and $\mathrm{C}_{17: 1}$ acid, respectively. Strain VS-752 ${ }^{\mathrm{T}}$ also differed from $H$. praevalens $\mathrm{GSL}^{\mathrm{T}}$ and $H$. acetoethylicus EIGI $^{\mathrm{T}}$ in the amount of plasmalogenlinked fatty acids. The major $(>7 \%)$ aldehydes in strain VS-752 ${ }^{\mathrm{T}}$ were $\mathrm{C}_{14: 0}$ and $\mathrm{C}_{16: 0}$ dimethylaldehydes, with $\mathrm{C}_{17: 0 \mathrm{cyc}}$ dimethylaldehyde as a minor component $(<7 \%)$. These com-

TABLE 2. Glucose fermentation products of $H$. salsugo VS-752

\begin{tabular}{|c|c|}
\hline Parameter & $\begin{array}{l}\text { Result for } \\
\text { H. salsugo VS-752 }\end{array}$ \\
\hline $\begin{array}{l}\text { Glucose consumed (mmol/liter) } \\
\text { Products formed (mmol/liter) }\end{array}$ & $5.7 \pm 0.1$ \\
\hline 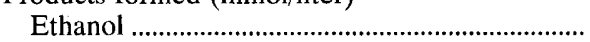 & $6.0 \pm 0.0$ \\
\hline Acetate & $8.4 \pm 0.3$ \\
\hline $\mathrm{CO}_{2}$ & $9.7 \pm 0.2$ \\
\hline $\mathrm{H}_{2}$ & $2.1 \pm 0.1$ \\
\hline very & 112 \\
\hline 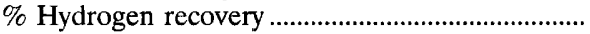 & 107 \\
\hline
\end{tabular}

${ }^{a}$ Cultures were grown as described in the text. Values represent means \pm standard deviations of two replicates.
TABLE 3. Cellular fatty acid compositions of $H$. salsugo VS-752 ${ }^{\mathrm{T}}$, $H$. praevalens $\mathrm{GSL}^{\mathrm{T}}$, and $H$. acetoethylicus $\mathrm{EIGI}^{\mathrm{T} a}$

\begin{tabular}{|c|c|c|c|}
\hline \multirow[b]{2}{*}{ Compound $^{b}$} & \multicolumn{3}{|c|}{ Cellular fatty acid composition $(\%)^{c}$} \\
\hline & $\begin{array}{l}\text { H. salsugo } \\
\text { VS-752 }\end{array}$ & $\begin{array}{l}\text { H. praevalens } \\
\text { GSL }^{\mathrm{T}}\end{array}$ & $\begin{array}{l}\text { H. acetoethylicus } \\
\text { EIGI }^{\mathrm{T}}\end{array}$ \\
\hline $\mathrm{C}_{10: 0}$ FAME & 0.5 & 0.6 & 0.3 \\
\hline $\mathrm{C}_{10: 0}$ 3-OH FAME & 0.2 & 0.9 & 3.2 \\
\hline $\mathrm{C}_{12: 0}$ FAME & 1.5 & 0.3 & 0.7 \\
\hline $\begin{array}{l}\mathrm{C}_{12: 0} \text { 3-OH FAME or } \mathrm{C}_{13: 0} \\
\text { DMA }\end{array}$ & 4.3 & 2.7 & 3.5 \\
\hline $\mathrm{C}_{14: 1}$ cis-9 FAME & & 0.6 & 0.6 \\
\hline $\mathrm{C}_{\text {14:0 }}$ FAME & 15.3 & 7.9 & 10.2 \\
\hline $\mathrm{C}_{14: 0}$ DMA & 7.0 & 0.5 & 1.0 \\
\hline $\mathrm{C}_{16: 0}$ ALDE & 4.0 & 0.5 & 0.4 \\
\hline $\mathrm{C}_{15: 0}$ FAME & & 0.5 & \\
\hline $\begin{array}{l}\mathrm{C}_{15: 0} \text { DMA or } \mathrm{C}_{14: 0} 3-\mathrm{OH} \\
\text { FAME }\end{array}$ & 0.9 & 0.1 & 0.2 \\
\hline $\mathrm{C}_{16: 1}$ cis-7 FAME & 4.3 & 11.4 & 12.0 \\
\hline $\mathrm{C}_{16: 1}$ cis-9 FAME & 4.9 & 34.1 & 33.9 \\
\hline $\mathrm{C}_{16: 1}$ cis-11 FAME & 0.8 & 6.8 & 5.3 \\
\hline $\mathrm{C}_{16: 0}$ FAME & 12.2 & 22.7 & 17.6 \\
\hline $\begin{array}{l}\mathrm{C}_{15: 0} \text { ante-3-OH FAME or } \\
\mathrm{C}_{16: 1} \text { cis-7 DMA }\end{array}$ & 1.5 & 0.5 & 0.6 \\
\hline $\mathrm{C}_{16: 1}$ cis-9 DMA & 1.6 & 2.7 & 3.7 \\
\hline $\mathrm{C}_{16: 0}$ DMA & 26.1 & 3.1 & 2.8 \\
\hline $\mathrm{C}_{17: 1}$ cis-9 FAME & & 0.2 & \\
\hline $\mathrm{C}_{17: 1}$ cis-11 FAME & & 0.4 & \\
\hline $\mathrm{C}_{17: 0}$ FAME & & 0.1 & \\
\hline $\mathrm{C}_{17: 0 \mathrm{cyc}}$ FAME & 7.0 & & 0.9 \\
\hline $\mathrm{C}_{17: 0 \mathrm{cyc}} \mathrm{DMA}$ & 3.7 & & 0.4 \\
\hline $\mathrm{C}_{18: 1}$ cis-9 FAME & & 0.6 & 0.4 \\
\hline $\mathrm{C}_{16: 0} 3-\mathrm{OH}$ FAME & 1.0 & & \\
\hline $\begin{array}{l}\mathrm{C}_{18: 1} \mathrm{c} 11 / \mathrm{t} 9 / \mathrm{t} 6 \mathrm{FAME} \text { or un } \\
17.834\end{array}$ & 0.3 & 1.1 & 0.6 \\
\hline $\mathrm{C}_{18: 1}$ cis-13 FAME & & & 0.2 \\
\hline $\mathrm{C}_{18: 0}$ FAME & & 0.5 & 0.5 \\
\hline
\end{tabular}

${ }^{a}$ Cultures were grown as described in text.

${ }^{b}$ FAME, fatty acid methyl ester; 3-OH, 3-hydroxy; 2-OH, 2-hydroxy; ALDE, aldehyde; DMA, dimethyl aldehyde; un, unknown; cyc, cyclic; ante, antesio.

c Percentage of compound.

pounds were minor components in $H$. praevalens $\mathrm{GSL}^{\mathrm{T}}$ and $H$. acetoethylicus $\mathrm{EIGI}^{\mathrm{T}}$.

DNA base composition. The $\mathrm{G}+\mathrm{C}$ content of the DNA was $34 \mathrm{~mol} \%$.

Phylogeny. A matrix of sequence similarity values for $H$. salsugo VS-752 ${ }^{\mathrm{T}}$, related halophiles, and several representative members of the clostridia is shown in Table 4. The phylogenetic tree derived from these data is shown in Fig. 3. The $16 \mathrm{~S}$ rRNA sequence analysis showed that $H$. salsugo VS-752 ${ }^{\mathrm{T}}$ was specifically related to $H$. praevalens $\mathrm{GSL}^{T}$ and that the sporeforming halophile $S$. lortetii $\mathrm{MD}-2^{\mathrm{T}}$ was a member of the same line of descent as the Haloanaerobium species. Oligonucleotide cataloging of $16 \mathrm{~S}$ rRNA indicated previously that $H$. halobius MD- ${ }^{\mathrm{T}}$ was related to $H$. praevalens $\mathrm{GSL}^{\mathrm{T}}$ and that these species could be placed together into a new family, the Haloanaerobiaceae (22). 16S rRNA oligonucleotide (hexamer and larger) analysis confirmed that $H$. salsugo VS-752 ${ }^{\mathrm{T}}$ was specifically related to $H$. praevalens $\mathrm{GSL}^{\mathrm{T}}$, with 30 oligonucleotides common to both species and exclusive of $H$. halobius MD $-1^{\mathrm{T}}$ and with no oligonucleotides common to $H$. salsugo VS-752 $2^{\mathrm{T}}$ and $H$. halobius $\mathrm{MD}-1^{\mathrm{T}}$ exclusive of $H$. praevalens GSL $^{\mathrm{T}}$ (data not shown). There were 24 16S rRNA oligonucleotides common to all three species, confirming their phylogenetic relationship.

$H$. salsugo VS-752 $2^{\mathrm{T}}$ belongs to the class of bacteria defined 
TABLE 4. Dissimilarity matrix from comparisons of $16 \mathrm{~S}$ rRNA sequences of species related to $H$. salsugo VS-752 ${ }^{\mathrm{T}}$ and clostridia

\begin{tabular}{|c|c|c|c|c|c|c|c|c|c|c|c|c|c|c|}
\hline \multirow[b]{2}{*}{ Organism $^{a}$} & \multicolumn{14}{|c|}{$\%$ Dissimilarity (evolutionary distance) to ${ }^{b}$ : } \\
\hline & 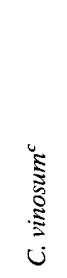 & 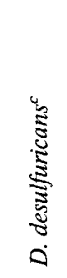 & 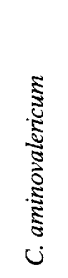 & 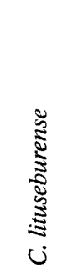 & 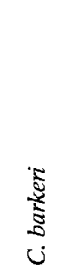 & 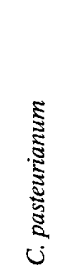 & 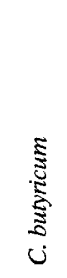 & $\begin{array}{l}\tilde{\Xi} \\
\stackrel{5}{\circ} \\
\vdots \\
\dot{s}\end{array}$ & 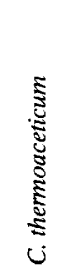 & 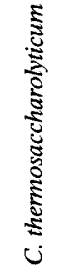 & 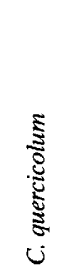 & $\begin{array}{l}\mathbf{E} \\
\frac{5}{5} \\
\Sigma\end{array}$ & $\begin{array}{l}\frac{8}{5} \\
\frac{5}{5} \\
\frac{5}{5} \\
\dot{z}\end{array}$ & 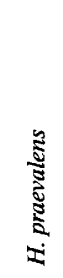 \\
\hline D. desulfuricans ${ }^{c}$ & 21.9 & & & & & & & & & & & & & \\
\hline C. aminovalericum & 22.5 & 22.1 & & & & & & & & & & & & \\
\hline C. lituseburense & 25.7 & 22.5 & 15.4 & & & & & & & & & & & \\
\hline C. barkeri & 22.5 & 22.1 & 19.2 & 18.4 & & & & & & & & & & \\
\hline C. pasteurianum & 24.4 & 24.3 & 18.0 & 18.3 & 18.1 & & & & & & & & & \\
\hline C. butyricum & 25.0 & 25.0 & 17.7 & 17.6 & 19.9 & 7.9 & & & & & & & & \\
\hline S. wolfei & 23.1 & 20.6 & 19.8 & 19.9 & 19.7 & 19.6 & 19.5 & & & & & & & \\
\hline C. thermoaceticum & 22.7 & 21.0 & 20.6 & 20.8 & 18.1 & 18.6 & 19.7 & 17.6 & & & & & & \\
\hline C. thermosaccharolyticum & 21.6 & 19.0 & 18.9 & 18.1 & 17.7 & 18.2 & 19.8 & 14.4 & 14.1 & & & & & \\
\hline C. quercicolum & 25.5 & 24.0 & 21.4 & 21.6 & 20.0 & 21.1 & 23.4 & 20.6 & 19.5 & 17.4 & & & & \\
\hline H. chlorum & 21.9 & 21.9 & 21.7 & 21.2 & 20.6 & 18.1 & 20.9 & 17.1 & 17.9 & 16.6 & 16.1 & & & \\
\hline H. salsugo & 25.8 & 24.9 & 25.3 & 22.7 & 23.1 & 22.5 & 23.9 & 23.7 & 21.1 & 21.8 & 22.1 & 23.5 & & \\
\hline H. praevalens & 26.2 & 25.9 & 25.1 & 23.4 & 24.2 & 23.5 & 24.1 & 24.0 & 22.5 & 21.5 & 23.0 & 25.3 & 4.3 & \\
\hline S. lortetii & 25.6 & 23.6 & 23.3 & 21.4 & 22.2 & 22.4 & 23.1 & 23.4 & 20.9 & 18.9 & 22.4 & 23.2 & 18.3 & 18.4 \\
\hline
\end{tabular}

${ }^{a}$ Genus names and strain designations are given in the text.

${ }^{b}$ Percentages of dissimilarity were determined from the number of changes per 100 nucleotides.

${ }^{c} C$. vinosum and $D$. desulfuricans are members of the gamma and delta subclasses, respectively, of the Proteobacteria.

by gram-positive bacteria whose DNA have a relatively low $\mathrm{G}+\mathrm{C}$ content (moles percent), the clostridia (5). The halophilic anaerobes $H$. salsugo VS-752 ${ }^{\mathrm{T}}, H$. praevalens $\mathrm{GSL}^{\mathrm{T}}, H$. halobius $\mathrm{MD}-1^{\mathrm{T}}$, and $S$. lortetii $\mathrm{MD}-2^{\mathrm{T}}$ probably form an

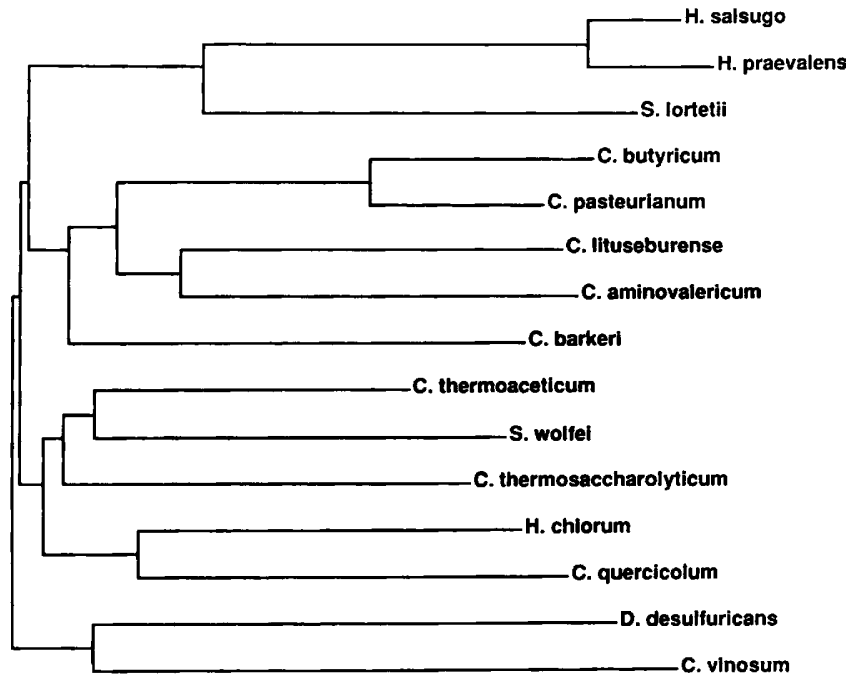
anaerobic, halophilic bacteria and clostridia. The phylogenetic tree was constructed by using the disimilarities in 16S rRNA sequence shown in Table 4 and the algorithm of De Soete (6). The total horizontal distance between two species indicates the level of difference between their sequence. Bar, $5 \%$ difference ( 0.05 evolutionary distance unit). order-level line of descent within the clostridia. This lineage is supported phenotypically by the fact that $S$. lortetii $\mathrm{MD}-2^{\mathrm{T}}$ and $H$. halobius $\mathrm{MD}-1^{\mathrm{T}}$ form spores. Other major lines of descent within the clostridia include the rRNA homology groups I and II, represented by $C$. butyricum, $C$. pasteurianum, and $C$. lituseburense (11); thermophilic bacteria, represented by $C$. thermoaceticum and $C$. thermosaccharolyticum (26); and members of the family Heliobacteriaceae (15), represented by $H$. chlorum (Fig. 3). The outgroup used in Fig. 3 included $C$. vinosum and $D$. desulfuricans, species in the gamma and delta subclasses, respectively, of the Proteobacteria (7).

Characteristics that differentiate strain VS- $752^{\mathrm{T}}$ from the described fermentative halophilic anaerobic bacteria. The differences between $H$. salsugo VS-752 ${ }^{\mathrm{T}}$ and other described fermentative halophilic anaerobes are summarized in Table 5. Strain VS-752 ${ }^{\mathrm{T}}$ can be easily differentiated from members of the genera Sporohalobacter, Haloanaerobacter, and Haloincola by phylogenetic and phenotypic characteristics. Phenotypically, strain VS-752 ${ }^{\mathrm{T}}$ differs from the Sporohalobacter spp. in cell size, salt tolerance, lack of motility, pattern of glucose fermentation, cell membrane fatty acid composition, DNA base composition, and the lack of spores or gas vacuoles. Strain VS- $752^{\mathrm{T}}$ can be differentiated from $H$. chitinovorans $\mathrm{W} 5 \mathrm{C} 8^{\mathrm{T}}$ by its metabolic characteristics, lack of motility, cell size, and inability to use chitin as a growth substrate. Strain VS-752 ${ }^{\mathrm{T}}$ can be differentiated from $H$. saccharolytica $\mathrm{Z}-7787^{\mathrm{T}}$ because $H$. saccharolytica $\mathrm{Z}-7787^{\mathrm{T}}$ is motile, does not produce ethanol from glucose, has a broader salt tolerance range, has a distinctly different cellular fatty acid composition, and does not utilize sorbose, rhamnose, raffinose, and yeast extract as growth substrates. The glucose fermentation pattern, $\mathrm{pH}$ range, salt tolerance, and cellular fatty acid profiles of strain VS-752 $2^{\mathrm{T}}$ are also different from those of the anaerobic halophiles described by Shiba et al. (30) and Shiba (29).

Strain VS-752 ${ }^{\mathrm{T}}$ was similar in its pattern of glucose fermentation to the members of the genus Halobacteroides, producing 
TABLE 5. Characteristics of $H$. salsugo VS-752 ${ }^{\mathrm{T}}$ and the type strains of other fermentative halophilic anaerobic bacteria ${ }^{a}$

\begin{tabular}{|c|c|c|c|c|c|}
\hline Parameter & $\begin{array}{l}\text { H. salsugo } \\
\text { VS-752 }\end{array}$ & $\begin{array}{l}\text { H. praevalens } \\
\text { GSL }^{\mathrm{T}}\end{array}$ & $\begin{array}{l}\text { S. lortetii } \\
\mathrm{MD}^{\mathrm{T}} \mathrm{T}^{\mathrm{N}}\end{array}$ & $\begin{array}{l}\text { S. marismortui } \\
\text { DY-1 }\end{array}$ & $\begin{array}{l}\text { H. chitinovorans } \\
\text { W5C }^{\mathrm{T}}\end{array}$ \\
\hline Morphology & Rod & Rod & Rod & Rod & Rod \\
\hline Size $(\mu \mathrm{m})$ & $0.3-0.4$ by $2.6-4.0$ & $0.5-1.5$ & $0.5-0.6$ by $2.5-10.0$ & 0.6 by $3.0-13.0$ & 0.5 by $2.5-8.0$ \\
\hline Gram reaction & Negative & Negative & Negative & Negative & Negative \\
\hline Motility & - & - & + & + & + \\
\hline Spores & - & - & + & + & - \\
\hline Temperature range $\left({ }^{\circ} \mathrm{C}\right)$ & $23-51$ & $12-45$ & $25-50$ & $25-50$ & $30-45$ \\
\hline $\mathrm{pH}$ range & $5.6-8.0$ & $6.0-8.0$ & NR & NR & 7.0 \\
\hline $\begin{array}{l}\mathrm{NaCl} \text { concn range (\% [wt/ } \\
\text { vol]) }\end{array}$ & $6-24$ & $5-25$ & $6-12$ & $3-18$ & $3-29$ \\
\hline $\begin{array}{l}\text { Optimum } \mathrm{NaCl} \text { requirement } \\
(\%[\mathrm{wt} / \mathrm{vol}])\end{array}$ & 9 & 12.5 & $8-10$ & $3-12$ & 12 \\
\hline Generation time (h) & 9 & 4 & 8 & 0.6 & 2.5 \\
\hline DNA content $(\% \mathrm{G}+\mathrm{C})$ & 34 & 27 & 32 & 30 & 35 \\
\hline Sampling source & Oil brine & $\begin{array}{l}\text { Great Salt Lake, } \\
\text { Utah }\end{array}$ & Dead Sea & Dead Sea & Solar saltern \\
\hline $\begin{array}{l}\text { Glucose fermentation } \\
\text { products }\end{array}$ & $\mathrm{A}, \mathrm{E}, \mathrm{H}_{2} / \mathrm{CO}_{2}$ & $\mathrm{~A}, \mathrm{~B}, \mathrm{CO}_{2} / \mathrm{H}_{2}$ & $\mathrm{~A}, \mathrm{P}, \mathrm{B}, \mathrm{H}_{2}$ & $\mathrm{~A}, \mathrm{E}, \mathrm{B}, \mathrm{F}, \mathrm{CO}_{2} / \mathrm{H}_{2}$ & $\begin{array}{l}\mathrm{A}, \mathrm{iB}, \mathrm{H}_{2} / \\
\mathrm{CO}_{2}\end{array}$ \\
\hline $\begin{array}{l}\text { Cellular fatty acid } \\
\text { composition } \\
\text { Major }(>7 \%) \\
\text { Minor }(0.5-7 \%)\end{array}$ & $\begin{array}{l}C_{14: 0}, C_{16: 0}, C_{16: 1}, C_{17: 0 \mathrm{cyc}} \\
C_{10: 0}, C_{12: 0}, C_{15: 0}\end{array}$ & $\begin{array}{l}C_{14: 0}, C_{16: 0}, C_{16: 1} \\
C_{10: 0}, C_{12: 0}, C_{14: 1} \\
C_{15: 0}, C_{17: 1}, C_{18: 0}, \\
C_{18: 1}\end{array}$ & $\begin{array}{l}\mathrm{C}_{16: 0}, \mathrm{C}_{16: 1}, \\
\mathrm{C}_{12: 0}, \mathrm{C}_{14: 1}, \mathrm{C}_{15: 0} \\
\quad \mathrm{C}_{17: 0}, \mathrm{C}_{18: 0}, \mathrm{C}_{18: 1}\end{array}$ & $\begin{array}{l}C_{14: 0}, C_{16: 0}, C_{16: 1}, C_{18: 0} \\
C_{12: 0}, C_{14: 0}, C_{18: 1}\end{array}$ & $\begin{array}{l}\text { NR } \\
\text { NR }\end{array}$ \\
\hline
\end{tabular}

acetate, ethanol, $\mathrm{CO}_{2}$, and $\mathrm{H}_{2}$ as end products. Among the known species of the genus Halobacteroides, strain VS-752 differs considerably from $H$. halobius $\mathrm{MD}-1^{\mathrm{T}}, H$. halobius $\mathrm{Z}-7287^{\mathrm{T}}$, and H. lacunaris $\mathrm{Z}-7888^{\mathrm{T}}$ in cell size, lack of motility, doubling time, DNA base composition, and cell membrane fatty acid composition. Strain VS-752 $2^{\mathrm{T}}$ also differs from $H$. halobius strains phylogenetically and in its inability to form spores. Strain VS-752 ${ }^{\mathrm{T}}$ was most similar to $H$. acetoethylicus $\mathrm{EIGI}^{\mathbf{T}}$ in its cell size and some physiological characteristics. However, strain VS-752 ${ }^{\mathrm{T}}$ differed from $H$. acetoethylicus $\mathrm{EIGI}^{\mathrm{T}}$ in substrate utilization (Table 1), cell membrane fatty acid composition (Table 3), and lack of motility. Strain VS-752 also differed from $H$. acetoethylicus EIGI $^{\mathrm{T}}$ in its magnesium tolerance. Magnesium concentrations higher than $200 \mathrm{mM}$ inhibited the growth of $H$. acetoethylicus $\mathrm{EIGI}^{\mathrm{T}}$ (27). Magnesium chloride concentrations up to $1.0 \mathrm{M}$ in the presence of 2.0 $\mathrm{M} \mathrm{NaCl}$ in growth medium did not inhibit the growth of strain VS-752 ${ }^{\mathrm{T}}$ (data not shown). There have been no comparative taxonomic studies between $H$. acetoethylicus EIGI $^{\mathrm{T}}$ and other members of the genus Halobacteroides or with other members of the family Haloanaerobiaceae. The phylogenetic status of $H$. acetoethylicus $\mathrm{EIGI}^{\mathrm{T}}$ in the family Haloanaerobiaceae has not been determined.

Analysis of the 16S rRNA oligonucleotide catalogs indicated that strain VS-752 ${ }^{\mathrm{T}}$ was closely related to $H$. praevalens $\mathrm{GSL}^{\mathrm{T}}$. However, the phenotypic characteristics of strain VS-752 ${ }^{\mathrm{T}}$ are considerably different from those of $H$. praevalens $\mathrm{GSL}^{\mathrm{T}}$. Morphologically, cells of strain VS- $752^{\mathrm{T}}$ are thinner than cells of $H$. praevalens GSL ${ }^{\mathbf{T}}$. Metabolically, strain VS-752 $2^{\mathrm{T}}$ differs from $H$. praevalens $\mathrm{GSL}^{\mathrm{T}}$ in its ability to use arabinose, galactose, lactose, melizitose, melibiose, pyruvate, rhamnose, raffinose, sucrose, L-sorbose, trehalose, and D-xylose as growth substrates and in its inability to use pectin as a growth substrate (Table 1). Strain VS-752 ${ }^{\mathrm{T}}$ also differs from $H$. praevalens $\mathrm{GSL}^{\mathrm{T}}$ in the products produced from glucose fermentation. Strain VS-752 ${ }^{\mathrm{T}}$ makes acetate, ethanol, $\mathrm{CO}_{2}$, and $\mathrm{H}_{2}$, while $H$. praevalens $\mathrm{GSL}^{\mathrm{T}}$ makes acetate, butyrate, $\mathrm{H}_{2}$, and $\mathrm{CO}_{2}$ from glucose. The $\mathrm{G}+\mathrm{C}$ content (moles percent) of strain $\mathrm{VS}-752^{\mathrm{T}}$ is significantly different from that of $H$. praevalens $\mathrm{GSL}^{\mathrm{T}}$. The $\mathrm{G}+\mathrm{C}$ content of strain VS-752 $2^{\mathrm{T}}$ is $34 \mathrm{~mol} \%$, while that of $H$. praevalens $\mathrm{GSL}^{\mathrm{T}}$ is $27 \mathrm{~mol} \%$. The cell membrane fatty acid composition of strain VS-752 ${ }^{\mathrm{T}}$ also differs from that of $H$. praevalens GSL $^{\mathrm{T}}$ (Table 3). A characteristic common to both $H$. praevalens GSL ${ }^{\mathrm{T}}$ and strain VS-752 ${ }^{\mathrm{T}}$ is their lack of motility. $H$. praevalens $\mathrm{GSL}^{\mathrm{T}}$ and strain VS-752 ${ }^{\mathrm{T}}$ are the only nonmotile halophiles in the family Haloanaerobiaceae.

The significant phenotypic and genotypic differences between strain VS-752 ${ }^{\mathrm{T}}$ and the described members of the genera Sporohalobacter, Haloanaerobacter, Haloincola, and Halobacteroides prevent the inclusion of strain VS-752 ${ }^{\mathrm{T}}$ in any of these genera. The closer phylogenetic relationship of strain VS-752 $2^{\mathrm{T}}$ to $H$. praevalens GSL ${ }^{\mathrm{T}}$ than to $S$. lortetii $\mathrm{MD}-2^{\mathrm{T}}$ or $H$. halobius $\mathrm{MD}-1^{\mathrm{T}}$ strongly suggests that strain $\mathrm{VS}-752^{\mathrm{T}}$ is a member of the genus Haloanaerobium. Since there are considerable phylogenetic and phenotypic differences between strain VS-752 $2^{\mathrm{T}}$ and $H$. praevalens $\mathrm{GSL}^{\mathrm{T}}$, and since there is a significant difference in the $\mathrm{G}+\mathrm{C}$ content (moles percent) between the two organisms, we propose that strain VS-752 be established as the type strain of a new species, $H$. salsugo, in the genus Haloanaerobium.

Description of Haloanaerobium salsugo sp. nov. $H$. salsugo, (sal.su'go. L. fem. n. salsugo, water impregnated with salt; brine, referring to isolation of this organism from oil field brine). $H$. salsugo has straight, rod-shaped cells that are 0.3 to 0.4 by 2.6 to $4 \mu \mathrm{m}$. Cells characteristically appear singly, in pairs, or occasionally as long chains and are nonmotile. The bacterium stains gram-negative and is non-spore forming. Colonies on complex medium are circular, entire, opaque, white, and 1 to $2 \mathrm{~mm}$ in diameter. Growth in liquid medium is uniform, with pellicle formation after $72 \mathrm{~h}$. Growth is inhibited by chloramphenicol, tetracycline, and penicillin but not by cycloheximide or azide.

The bacterium is obligately halophilic. The optimal $\mathrm{NaCl}$ concentration for growth is $9 \%$; growth occurs at $\mathrm{NaCl}$ concentrations of between 6 and $24 \%$. NaCl is specifically required, with no growth observed at $\mathrm{NaCl}$ concentrations less 
TABLE 5-Continued

\begin{tabular}{|c|c|c|c|c|}
\hline H. saccharolytica $\mathrm{Z}-7787^{\mathrm{T}}$ & $\begin{array}{l}\text { H. halobius } \\
\text { MD-1 } 1^{\mathrm{T}}\end{array}$ & $\begin{array}{l}\text { H. halobius } \\
\text { Z-7287 }\end{array}$ & $\begin{array}{l}\text { H. lacunaris } \\
\text { Z-7888 }^{\mathrm{T}}\end{array}$ & $\begin{array}{l}\text { H. acetoethylicus } \\
\text { EIGI }^{\mathrm{T}}\end{array}$ \\
\hline Rod & Rod & Rod & Rod & Rod \\
\hline $0.5-0.7$ by $1.0-1.5$ & $0-5$ by $10.0-20.0$ & $0.3-0.5$ by $2.0-10.0$ & $0.7-1.0$ by $0.5-6.0$ & $0.4-0.7$ by $1.0-1.6$ \\
\hline Negative & Negative & Negative & Negative & Negative \\
\hline+ & + & + & + & + \\
\hline - & + & + (oligospores) & - & - \\
\hline $15-47$ & $37-45$ & $28-47$ & $25-52$ & $15-45$ \\
\hline $6.0-8.0$ & NR & $6.5-8.0$ & $6.0-8.0$ & $5.4-8.0$ \\
\hline $3-30$ & $8-17$ & $10-30$ & $10-30$ & $6-20$ \\
\hline 10 & $9-14$ & $10-15$ & $15-18$ & 10 \\
\hline 3.9 & 1 & 2 & $2.9-4.5$ & $7.8-9.5$ \\
\hline 31 & 31 & 31 & 32 & 32 \\
\hline Lake Sivash & Dead Sea & Lake Sivash & Lake Chokrack & Gulf of Mexico \\
\hline $\mathrm{A}, \mathrm{H}_{2} / \mathrm{CO}_{2}$ & $\mathrm{~A}, \mathrm{E}, \mathrm{H}_{2} / \mathrm{CO}_{2}$ & $\mathrm{~A}, \mathrm{E}, \mathrm{CO}_{2} / \mathrm{H}_{2}$ & $\mathrm{~A}, \mathrm{E}, \mathrm{CO}_{2} / \mathrm{H}_{2}$ & $\mathrm{~A}, \mathrm{E}, \mathrm{CO}_{2} / \mathrm{H}_{2}$ \\
\hline $\mathrm{C}_{15: 1}, \mathrm{C}_{16: 0}, \mathrm{C}_{16: 1}$ & $\mathrm{C}_{14: 0}, \mathrm{C}_{16: 0}, \mathrm{C}_{16.1}$ & $\mathrm{C}_{16: 0}, \mathrm{C}_{16: 1}$ & $\mathrm{C}_{16: 0}, \mathrm{C}_{16: 1}$ & $C_{14: 0}, C_{16: 0}, C_{16: 1}$ \\
\hline $\begin{array}{l}C_{14: 0}, C_{14: 1}, C_{15: 0}, C_{16: 0} \\
C_{17: 0}, C_{17: 1}, C_{18: 0}, C_{18: 1}\end{array}$ & $C_{14: 1}, C_{18: 0}, C_{18: 1}$ & $\begin{array}{l}\mathrm{C}_{14: 0}, \mathrm{C}_{14: 1}, \mathrm{C}_{18: 0}, \\
\mathrm{C}_{18: 1}\end{array}$ & $\begin{array}{l}\mathrm{C}_{14: 0}, \mathrm{C}_{14: 1}, \mathrm{C}_{18: 0} \\
\mathrm{C}_{18: 1}\end{array}$ & $\begin{array}{c}\mathrm{C}_{10: 0}, \mathrm{C}_{12: 0}, \mathrm{C}_{14: 1}, \mathrm{C}_{15: 0}, \\
\mathrm{C}_{17: 0 \mathrm{cyc}}, \mathrm{C}_{18: 0}, \mathrm{C}_{18: 1}\end{array}$ \\
\hline
\end{tabular}

than $6 \%$ or in medium with potassium, lithium, magnesium, or ammonium salts or sodium bromide, sodium nitrate, sodium sulfate, or sodium thiosulfate. The temperature range is 22 to $51^{\circ} \mathrm{C}$, with the fastest growth occurring at $40^{\circ} \mathrm{C}$. The $\mathrm{pH}$ range is 5.6 to 8.0 , with the optimum for growth at $\mathrm{pH} 6.1$.

The bacterium is strictly anaerobic, is catalase and oxidase negative, and has a fermentative metabolism. The end products of glucose fermentation are acetate, ethanol, $\mathrm{CO}_{2}$, and $\mathrm{H}_{2}$. The molar growth yield was $24.5 \pm 0.3 \mathrm{~g}$ (dry weight) of cells per mol of glucose.

The following compounds supported growth in mineral salts medium: L-arabinose, $\mathrm{N}$-acetylglucosamine, fructose, galactose, glucosamine, D-glucose, lactose, maltotriose, melizitose, D-mannose, maltose, melibiose, pyruvate, D-ribose, rhamnose, raffinose, sucrose, L-sorbose, trehalose, D-xylose, and yeast extract.

The following compounds did not support growth in mineral salts medium: L-alanine, L-ascorbate, adonitol, betaine, butyrate, chitin, crotonate, Casamino Acids, dextran, dextrin, dulcitol, ethylene glycol, formate, fucose, fumarate, glycerol, glutamate, glycine, glycogen, D-gluconate, inositol, inulin, Llysine, lactate, malate, methanol, mannitol, methionine, pectin, proline, propionate, peptone, starch, succinate, sarcosine, sorbitol, salicin, trypticase, whey, and xylan. Amino acid mixtures such as alanine-glycine, leucine-proline, isoleucine-tryptophan, valine-ornithine, phenylalanine-leucine, and histidine-sarcosine were not utilized.

The major $(>7 \%)$ cellular fatty acids are $\mathrm{C}_{14: 0}, \mathrm{C}_{16: 0}, \mathrm{C}_{16: 1}$, and $\mathrm{C}_{17: 0 \text { cyc }}$ acids. The minor $(0.5$ to $7 \%)$ fatty acids are $C_{10: 0}$, $\mathrm{C}_{12: 0}$, and $\mathrm{C}_{15: 0}$ acids.

The $\mathrm{G}+\mathrm{C}$ content of the DNA is $34 \mathrm{~mol} \%$ (as determined by HPLC).

The habitat is hypersaline petroleum reservoir production fluid from Payne County, Okla.
The type strain is VS-752, which has been deposited in the American Type Culture Collection as ATCC 51327.

\section{ACKNOWLEDGMENTS}

We thank Kim Fowler, Woody Jenkins, Bryan Hopkins, Richard Raiders, and Tue Tue Liu for technical assistance, Linda Mandelco and James Sechrest for 16S rRNA sequencing, and the staff of the Samuel Roberts Noble Electron Microscopy Laboratory for assistance with the electron microscopy.

This work was supported by contracts DE-AC 22-90BC14662 and DE-FG6589ER-14003 from the Department of Energy. Part of this work was supported by grant BSR 8705352 from the National Science Foundation (C.R.W.) and grant CA 52955 from the National Institutes of Health (R.S.T.).

\section{REFERENCES}

1. Balch, W. E., and R. S. Wolfe. 1976. New approach to the cultivation of methanogenic bacteria: 2-mercaptoethanesulfonic acid (HS-CoM)-dependent growth of Methanobacterium ruminantium in a pressurized atmosphere. Appl. Environ. Microbiol. 32:781-791.

2. Belyaev, S. S., I. A. Charackhchian, I. A. Borzenkov, E. I. Milyokhina, and V. G. Kuzetsova. 1990 . The activities of microbiological processes in stratal waters of oil fields, p. 425-443. In C. B. Fliermans and T. C. Hazen (ed.), Proceedings of the 1st International Symposium on Microbiology of the Deep Subsurface. WSRC Information Services, Aiken, S.C.

3. Bhupathiraju, V. K., M. J. McInerney, and R. M. Knapp. 1993. Pretest studies for a microbially enhanced oil recovery field pilot in a hypersaline oil reservoir. Geomicrobiol. J. 11:19-34.

4. Bhupathiraju, V. K., P. K. Sharma, M. J. McInerney, R. M. Knapp, K. Fowler, and W. Jenkins. 1991. Isolation and characterization of novel halophilic anaerobic bacteria from oil field brines. Dev. Petrol. Sci. 31:131-143. 
5. Cato, E. P., and E. Stackebrandt. 1989. Taxonomy and phylogeny, p. 1-26. In N. P. Minton and D. J. Clarke (ed.), Clostridia. Plenum Press, New York.

6. De Soete, G. 1983. A least square algorithm for fitting additive trees to proximity data. Psychometrika 48:621-626.

7. DeWeerd, K. A., L. Mandelco, R. S. Tanner, C. R. Woese, and J. M. Suflita. 1990. Desulfomonile tiedjei gen. nov. and sp. nov., a novel anaerobic, dehalogenating, sulfate-reducing bacterium. Arch. Microbiol. 154:23-30.

8. Dussault, H. P. 1955. An improved technique for staining red halophilic bacteria. J. Bacteriol. 70:484-485.

9. Gervertz, D., J. R. Paterek, M. E. Davey, and W. A. Wood. 1991. Isolation and characterization of anaerobic halophilic bacteria from oil reservoir brines. Dev. Petrol. Sci. 31:115-129.

10. Jenneman, G. E., M. J. McInerney, and R. M. Knapp. 1986. Effect of nitrate on biogenic sulfide production. Appl. Environ. Microbiol. 51:1205-1211.

11. Johnson, J. L., and B. S. Francis. 1975. Taxonomy of the clostridia: ribosomal ribonucleic acid homologies among species. J. Gen. Microbiol. 88:229-244.

12. Jukes, T. H., and C. R. Cantor. 1969. Evolution of protein molecules, p. 21-132. In H. N. Monro (ed.), Mammalian protein metabolism, vol. 3. Academic Press, New York.

13. Lane, D. J., B. Pace, G. J. Olsen, D. A. Stahl, M. L. Sogin, and N. R. Pace. 1985. Rapid determination of 16S ribosomal RNA sequences for phylogenetic analysis. Proc. Natl. Acad. Sci. USA 82:6955-6959.

14. Liaw, H. J., and R. A. Mah. 1992. Isolation and characterization of Haloanaerobacter chitinovorans gen. nov., sp. nov., a halophilic, anaerobic, chitinolytic bacterium from a solar saltern. Appl. Environ. Microbiol. 58:260-266.

15. Madigan, M. T. 1992. The family Heliobacteriaceae, p. 1981-1992. In A. Balows, H. G. Trüper, M. Dworkin, W. Harder, and K. H. Schleifer (ed.), The prokaryotes, 2nd ed., vol. 2. Springer-Verlag, New York.

16. Marmur, J. 1961. A procedure for the isolation of deoxyribonucleic acid from micro-organisms. J. Mol. Biol. 3:208-218.

17. Mesbah, M., U. Premachandran, and W. B. Whitman. 1989. Precise measurement of the $\mathrm{G}+\mathrm{C}$ content of deoxyribonucleic acid by high-performance liquid chromatography. Int. J. Syst. Bacteriol. 39:159-167.

18. Miller, L. T. 1982. Single derivatization method for routine analysis of bacterial whole-cell fatty acid methyl esters, including hydroxy acids. J. Clin. Microbiol. 16:584-586.

19. Moss, C. W., P. L. Wallace, D. G. Hollis, and R. E. Weaver. 1988. Cultural and chemical characterization of CDC groups EO-2, M-5, and M-6, Moraxella (Moraxella) species, Oligella urethralis, Acinetobacter species, and Psychrobacter immobilis. J. Clin. Microbiol. 26:484-492.

20. Ni, S., and D. R. Boone. 1991. Isolation and characterization of a dimethyl sulfide-degrading methanogen, Methanolobus siciliae HI350, from an oil well, characterization of $M$. siciliae $\mathrm{T} 4 / \mathrm{M}^{\mathrm{T}}$, and emendation of $M$. siciliae. Int. J. Syst. Bacteriol. 41:410-416.

21. Oren, A. 1983. Clostridium lortetii sp. nov. a halophilic obligatorily anaerobic bacterium producing endospores with attached gas vacuoles. Arch. Microbiol. 136:42-48.

22. Oren, A., B. J. Paster, and C. R. Woese. 1984. Haloanaerobiaceae: a new family of moderately halophilic, obligatory anaerobic bacteria. Syst. Appl. Microbiol. 5:71-80.

23. Oren, A., H. Pohla, and E. Stackebrandt. 1987. Transfer of Clostridium lortetii to a new genus Sporohalobacter gen. nov. as Sporohalobacter lortetii comb. nov., and description of Sporohalobacter marismortui sp. nov. Syst. Appl. Microbiol. 9:239-246.
24. Oren, A., W. G. Weisburg, M. Kessel, and C. R. Woese. 1984. Halobacteroides halobius gen. nov., sp. nov, a moderately halophilic anaerobic bacterium from the bottom sediments of the Dead Sea. Syst. Appl. Microbiol. 5:58-70.

25. Oyaizu, H., B. Debrunner-Vossbrinck, L. Mandelco, J. A. Studier, and C. R. Woese. 1987. The green non-sulfur bacteria: a deep branching in the eubacterial line of descent. Syst. Appl. Microbiol. 9:47-53.

26. Rainey, F. A., and E. Stackebrandt. 1993. Phylogenetic analysis of the bacterial genus Thermobacteroides indicates an ancient origin of Thermobacteroides proteolyticus. Lett. Appl. Microbiol. 16:282286.

27. Rengpipat, S., T. A. Langworthy, and J. G. Zeikus. 1988. Halobacteroides acetoethylicus sp. nov., a new obligately anaerobic halophile isolated from deep subsurface hypersaline environments. Syst. Appl. Microbiol. 11:28-35.

28. Sassar, M. 1990. Identification of bacteria by gas chromatography of cellular fatty acids. MIDI technical note 101. MIDI, Inc., Newark, Del.

29. Shiba, H. 1991. Anaerobic halophiles, p. 191-211. In K. Horikoshi and W. D. Grant (ed.), Superbugs, microorganisms in extreme environments. Japan Scientific Societies Press, Tokyo.

30. Shiba, H., H. Yamamoto, and K. Horikoshi. 1989. Isolation of strictly anaerobic halophiles from the aerobic surface sediments of hypersaline environments in California and Nevada. FEMS Microbiol. Lett. 57:191-196.

31. Smibert, R. M., and N. R. Krieg. 1981. General characterization, p. 409-443. In P. Gerhardt, R. G. E. Murray, R. N. Costilow, E. W. Nester, W. A. Wood, N. R. Krieg, and G. B. Phillips (ed.), Manual of methods for general bacteriology. American Society for Microbiology, Washington, D.C.

32. Tanner, R. S. 1989. Monitoring sulfate-reducing bacteria: comparison of enumeration media. J. Microbiol. Methods 10:83-90.

33. Tanner, R. S., L. M. Miller, and D. Yang. 1993. Clostridium ljungdahlii sp. nov., an acetogenic species in clostridial rRNA homology group I. Int. J. Syst. Bacteriol. 43:232-236.

34. Ventosa, A. 1988. Taxonomy of moderately halophilic heterotrophic eubacteria, p. 71-84. In F. Rodriguez-Valera (ed.), Halophilic bacteria, vol. 1. CRC Press, Inc., Boca Raton, Fla.

35. Vreeland, R. H., and L. I. Hochstein (ed.). 1992. The biology of halophilic bacteria. CRC Press, Inc., Boca Raton, Fla.

36. Zeikus, J. G., P. W. Hegge, T. E. Thompson, T. J. Phelps, and T. A. Langworthy. 1983. Isolation and description of Haloanaerobium praevalens gen. nov. sp. nov., an obligately anaerobic halophile common to Great Salt Lake sediments. Curr. Microbiol. 9:225234.

37. Zhao, H., D. Yang, C. R. Woese, and M. P. Bryant. 1993. Assignment of fatty acid- $\beta$-oxidizing syntrophic bacteria to Syntrophomonadaceae fam. nov. on the basis of 16S rRNA sequence analyses. Int. J. Syst. Bacteriol. 43:278-286.

38. Zhilina, T. N., V. V. Kevbrin, A. M. Lysenko, and G. A. Zavarzin. 1991. Saccharolytic anaerobic bacteria in a halophilic cyanobacterial mat. Microbiology 60:101-107.

39. Zhilina, T. N., L. V. Miroshinikova, G. A. Osipov, and G. A. Zavarzin. 1991. Halobacteroides lacunaris sp. nov., a new saccharolytic anaerobic extremely halophilic bacterium from a hypersaline Chokrack Lake. Microbiology 60:495-503.

40. Zhilina, T. N., G. A. Zavarzin, E. S. Bulygina, V. V. Kevbrin, G. A. Osipov, and K. M. Chumakov. 1992. Ecology, physiology and taxonomy studies on a new taxon of Haloanaerobiaceae, Haloincola saccharolytica gen. nov., sp. nov. Syst. Appl. Microbiol. 15:275-284. 